\title{
Teaching Literatures by Arabized Jews: Medieval and Modern
}

Many of the courses in Jewish Studies I teach at a German University involve medieval texts written by Arabized Jews. ${ }^{1}$ Though these texts seem to lack any relation to modern Arab-Jewish literature, I have come to the conclusion - and this will be my claim - that the challenges one faces when teaching medieval Arab-Jewish literature resemble those one faces when teaching modern literature written by Arabized Jews. In both cases, the challenges derive from the curricular structures, the "Fächerkanon," at German universities and from the background of the students I have the privilege to teach. To substantiate my claim, I outline three curricular challenges which, I think, pertain to the teaching of both medieval and modern Arab-Jewish literature and I present - in the manner of case studies - three courses I have taught on medieval Arab-Jewish literature whose interdisciplinary approach could also be applied to courses on modern literature written by Arabized Jews.

\section{In what context do we read and interpret Arab-Jewish literature?}

The first challenge is raised by the cultural narratives which often underlie the perception of and research on works written by Arabized Jews. For the medieval period these are the various generalizing conceptions of Arab-Jewish history, ranging from "Golden Age" depictions to neo-lachrymose conceptions. ${ }^{2}$ How one perceives Arabized Jews to have participated in the majority culture, how one conceives of cultural boundaries, and how one gauges the degree of inter-

1 To refer to Arabic-speaking Jews who participate in a culture in which Arabic is the main language I will be using the term 'Arabized Jew' as suggested by Ross Brann (2000) and Moshe Behar (2009) and I will be referring to 'Arab-Jewish' identity or literature following the example of Reuven Snir (2019). An alternative term, 'Arab Jew,' is also used often, but seems less suited because it also forms the center of recent, often vocal, cultural and political debates (Levy 2008, 2017).

2 Mark R. Cohen (2013) offers a succinct reflection on "golden age" conceptions. The term 'lachrymose' was introduced by Salo W. Baron (1939, 1963; see also Teller 2014) and more recently applied to the context of Arabized Jews by Mark R. Cohen (1991).

๑ OpenAccess. (c) 2020 Lukas Muehlethaler, published by De Gruyter. (cc))BY-NC-ND This work is licensed under the Creative Commons Attribution-NonCommercial-NoDerivatives 4.0 License. 
communal violence has a strong impact on the approach to Arab-Jewish literature and on its interpretation. The same holds true for the modern period. Though the cultural context of modern Arabized Jews is less remote in time, it has changed dramatically during the second half of the $20^{\text {th }}$ century. Contemporary perceptions and conceptions about relations between "Jews and Arabs" make it often difficult to conceive of the many ways in which Arabized Jews lived as part of the majority culture in different parts of the Arabic-speaking world. The great extent to which the various medieval and modern narratives of Arab-Jewish history are still functional is shown in the contemporary debates on the term 'Arab Jew' (Levy 2017).

\section{Is the literature of Arabized Jews Arabic literature?}

At first glance, the question whether the literature of Arabized Jews is Arabic literature appears nonsensical. During most of the medieval period, Arabic served as both the colloquial and the written language for a majority of Arabic Jews and was thus - based on rough demographic estimates - the language used by the vast majority of Jews living at that time. Jews contributed to many genres of Arabic literature. They also applied some of these genres to the Jewish religious tradition. This included both Rabbanite authors who commented on and continued the Rabbinic tradition and Karaite authors who rejected the Rabbinic tradition and aimed at replacing it. ${ }^{3}$ Rabbanite and Karaite Jews often wrote Arabic in the script they also used for the Hebrew language. This kind of Arabic writing is often termed Judaeo-Arabic, though scholars disagree on the exact definition and significance of this term (Khan 2017b, 2017a). Despite the central place of Arabic in the literature of Arabized Jews, Arabic (or Judaeo-Arabic) is not the only language they used for literary production. From the $10^{\text {th }}$ to at least the $16^{\text {th }}$ century, Arabized Jews write major works of various genres also in Hebrew. This includes both "Jewish" genres such as halakhic writings as well as more "general" genres such as poetry - both liturgical and "profane" - which was written in Hebrew, though most poets came to use meters and motifs of Arabic poetry. ${ }^{4}$ If we were to focus on works written in Arabic, we would miss out on

3 The best monograph on the medieval Jewish literature in the Arabic language is still the pioneering work by Moritz Steinschneider (1902).

4 Non-Hebraist English speakers can obtain a good "second-hand" impression of this tradition through the superb translations by Peter Cole (2007). 
important aspects of the multilingualism and the polyphony in the culture of Arabized Jews.

This requires in some sense a correction of a correction. Initially, the "outside" perspective on the medieval literature of Arabized Jews had focused on works written in Hebrew and on works later translated from Arabic into Hebrew. These works came to find their place on the proverbial Jewish bookshelf while most of the Arabic literary production of Arabized Jews became marginalized during the cultural and societal shifts of the later Middle Ages, which had Arabized Jews lose their former cultural hegemony. Arab-Jewish literature had to be "rediscovered" as part of the broader canon of Jewish literature, a rediscovery to which the proponents and contemporaries of the "Wissenschaft des Judentums" made major contributions. ${ }^{5}$ This rediscovery (and necessary correction) put (Judaeo-)Arabic literature at the very center of Arab-Jewish culture and it was their Hebrew prose production which became somewhat marginalized. Yet unless we understand Hebrew works (and in some sense the Hebrew translations of Judaeo-Arabic works) as an integral part of Arab-Jewish literature, we will have only a partial understanding of the culture of Arabized Jews. This is valid even more so because the two languages did not exist side-by-side, but interacted in various interesting ways. Judaeo-Arabic texts, especially texts in traditional genres, often show the impact of the Hebrew language on their vocabulary and syntax; Hebrew texts, in turn, echo Arabic syntax. ${ }^{6}$

Similar effects of multilingualism and polyphony seem to hold true for ArabJewish literature written in the Modern period. Arabized Jews write in languages other than Arabic, such as European languages or modern Hebrew and in some cases create works in more than one language. Their choice of language is often not free but determined by (forced) migration and cultural re-orientation.

Three well-known examples should suffice: Jacqueline Shohet Kahanoff (1917-1979) was born in Egypt as the daughter of an Iraqi Jewish father and Tunisian Jewish mother. She received her education in the United States and published in English, but in the mid-1950s immigrated to Israel. ${ }^{7}$ Sami Michael (Sāmī Mihầ'îl), born 1926 in Baghdad, wrote in Arabic, had to flee to Iran and in 1949

5 To be sure, these scholars focused on what they considered to be the "classical period" of Judaeo-Arabic literature, as the pioneering monograph by Steinschneider (1902) shows.

6 Even though Arabic was the literary language of a majority of Jews living in the Islamicate world, they also used (and adapted for their use) languages of other Islamicate cultures, such as Persian and Turkic languages.

7 In the case of Kahanoff, writing and publishing in English might not have been a choice, because her educational background did not provide her with sufficient knowledge in literary Arabic and Arabic literature (Starr and Somekh 2011). 
immigrated to Israel (he still holds Iraqi citizenship). He worked as a hydrologist and at the age of 45 started to publish in Hebrew. Ishāa Bār-Moshe (1927-2003) was born in Baghdad and immigrated to Israel in the 1950s. He continued to write in Arabic but, he, too, started to publish only in the 1970s. These few examples show that if one were to try to understand the literature of Arabized Jews as a whole based on works written in Arabic alone, one would obtain a lopsided image of that literary production. This is true also with regard to individual writers, especially those who wrote in more than one language.

\section{Is the literature of Arabized Jews "Jewish" literature?}

The third curricular challenge relates to the religious identity of the authors and the works they write. To what extent can we consider the literature of Arabized Jews to be "Jewish" literature? In the medieval Christian world, the cultural space of Jews became increasingly circumscribed and was generally limited. Most works written by Jews can be entered in the canon of "Jewish literature" because they are easily identifiable as such. They were either written in Hebrew - which also became the language of most scientific texts written by Jews from the $13^{\text {th }}$ century onward - or they were written for a Jewish audience or on Jewish topics. Though generalizing statements are rarely helpful, much evidence indicates that Jews in the medieval Christian world directly participated in the general culture much less than their Arab-speaking co-religionists in the Islamicate World. ${ }^{8}$

The question is of a much greater import for the social context of medieval Arabized Jews. Lower levels of inter-communal violence (as compared to the contemporaneous Christian West) and a shared language led to more permeable cultural boundaries between various communities and allowed Jews to participate in the general culture. This also meant that Jews contributed to many genres of Arabic literature that lacked denominational markings. One would not identify these works as "Jewish," nor would these works identify their authors as Jews. So much so that a sizeable part of the literature produced during the Middle Ages by Arabized Jews would fall outside of the scope of Jewish studies or related disciplines. The problem with an approach focusing on "Jewish" literature is

8 Gad Freudenthal (2012) provides a helpful discussion of factors contributing to the permeability of inter-communal boundaries in this context. 
not so much that it sidelines entire genres, e. g. scientific, philosophical, or medical writings, but that it considers the oeuvre of an author only in part.

If, for example, an author composes two treatises: a treatise on a topic that clearly relates to "Jewish" notions and another treatise that does not even allow the readers to identify the religious affiliation of its author, an approach interested only in Jewish aspects of that author's work would focus on the former treatise and ignore the latter. The image of an author's literary production and interests so obtained would be partial at best.

The same holds true for the modern period. Jewish authors contributed to the nahda, the "awakening" of Arabic culture during the late $19^{\text {th }}$ and early $20^{\text {th }}$ century (Behar and Ben-Dor Benite 2013; Snir 2006). The Lebanese women's rights activist Esther Moyal (1874-1948), for example, translated Western Literature into Arabic, worked as a journalist, and founded Arabic newspapers (Levy 2013). Focusing on her work as an activist for Jewish women's rights would not give her sufficient credit for her important contributions to Arabic literature. Jewish authors also contributed to new genres in Arabic literature and some of them continued to write in these genres (in both Arabic and Hebrew) after the exodus of Jews from Arab countries led to a decline in the number of Arabic texts written by Jews. The cultural dynamics enabling the participation of Arabized Jews in the renewal of Arabic literature and the change of these dynamics over the course of less than a century has been analyzed by Reuven Snir (2019) using as an example the genre of the Arabic short story.

The above examples and anecdotes are far too few to do justice to the long and rich cultural history of Arabized Jews. It is clear, however, that Arabized Jews participated in the general Arabic culture in different geographical areas during different periods. Some reflected in the works they wrote on their hybrid cultural identity; others did so in some of their works only or not at all. Approaching their literature by asking only questions related to their Jewish identity or to "Jewish topics" would result in a skewed image of Arab-Jewish literature and culture.

\section{To whom can we teach the literature of Arabized Jews?}

The curricular challenges mentioned so far suggest that teaching the modern literature of Arabized Jews requires an interdisciplinary effort. However, they also suggest that learning about this literature takes tremendous effort and demands exceptional preparation. For the medieval period, students should combine proficiency in Arabic, proficiency in Hebrew, and a grasp of many historical and cul- 
tural contexts with a thorough knowledge of the subject matters of various genres of texts (literature, halakha, exegesis, science, philosophy, etc.). For the modern period one would add to these requirements a knowledge of several western languages, literatures, and cultures. But do such students exist?

I have come to the conclusion that the perfect academic setting for teaching the medieval literature of Arabized Jews does not exist: There are no teachers perfectly qualified to teach all facets of this literature, nor are there students who are perfectly prepared to study this literature. What exists - and this is a source of wonderful surprise and constant encouragement - are the openness and the enthusiasm of students who want to learn about Arab-Jewish literature. All it takes is to choose didactic approaches that allow students from different disciplines and courses of study to collaborate. That these approaches can take very simple forms I would like to illustrate using the example of three courses on medieval Arab-Jewish literature I have taught in recent years.

My colleagues and I have been teaching medieval philosophy in its various languages following an interdisciplinary approach. This approach works particularly well for texts that were translated from Greek into Arabic and then into Latin, and Hebrew. It is less suited for those works by Arabized Jews which were translated neither into medieval Hebrew nor into any modern language. But with some preparation, teaching these texts can be highly rewarding. In a course on the $12^{\text {th }}$-century Jewish philosopher Abū l-Barakāt al-Baghdādī, for example, half the participants were students of philosophy and the other half students of Arabic and Jewish studies. Some of the students lacked the necessary language skills and others lacked a background in philosophy. To accommodate this heterogeneous group of participants it was sufficient to produce English draft translations of selected chapters and to co-teach the course with a colleague from the philosophy department of Humboldt University.

I experienced how a heterogeneous group of participants enriches the teaching and learning experience also when I taught a course on Aristotle's Poetics in Arabic and Hebrew. Among the participants were students from Jewish Studies, Arabic Studies, Islamic Studies, Classical Studies, Byzantine Studies, Religious Studies, and Comparative Literature. They had backgrounds in Greek, Syriac, Arabic, Hebrew, and Latin with all students having reading knowledge of at least one of these languages. We ended up reading selected passages from Aristotle's text, its Syriac and Arabic translations, as well as the Arabic and Hebrew versions of Averroes' commentary in all languages at the same time, so that each student was able to read the text of at least one literary tradition and engage in exchange and discussion with students reading the text in another tradition. Because of the varied background of the students, among them Arab Christians 
from Iraq and Syria and Arab Israelis, all participants had the opportunity to engage with this complex textual tradition in novel and often unexpected ways. ${ }^{9}$

Several times the initiative for interdisciplinary courses on Arab-Jewish literature has come from students. A few years ago, a group of students from Arabic Studies, Semitic studies and Jewish studies approached me, suggesting I teach an introductory course in Judaeo-Arabic literature. I did so and we had lots of fun. Last semester a different group approached me with the same wish. This time we decided that the only requirement to participate would be a working knowledge of Arabic; all other skills the students would acquire during the course. We decided that we would read both printed texts and texts in manuscript form from the Cairo Geniza, with topics ranging from intellectual history to letters by India traders. Each student contributed according to his or her background and all ended up reading texts in Judaeo-Arabic manuscripts.

The approach illustrated by these "case studies" can be adapted quite easily to the teaching of modern Arab-Jewish literature. All it takes is to allow students of different backgrounds to participate and contribute, to co-teach when appropriate, and to find a suitable blend of texts in the original languages and in translations. ${ }^{10}$ The key is, I think, to find the right mixture of didactic courage and academic humility in both teachers and students.

\section{Bibliography}

Alcalay, Ammiel. Keys to the garden: New Israeli writing. San Francisco: City Lights Books, 1996.

Baron, Salo W. “Emphases in Jewish History.” Jewish Social Studies 1 (1939): 15-38.

Baron, Salo W. "Newer Emphases in Jewish History." Jewish Social Studies 25 (1963): $235-248$.

Behar, Moshe. "What's in a Name? Socio-Terminological Formations and the Case for 'Arabized-Jews'." Social Identities 15.6 (2009): 747-771.

Behar, Moshe, and Zvi Ben-Dor Benite (Eds.). Modern Middle Eastern Jewish Thought: Writings on Identity, Politics, and Culture, 1893-1958. Waltham: Brandeis University Press, 2013.

Brann, Ross. 2000. "The Arabized Jews." The Cambridge History of Arabic Literature: The Literature of Al-Andalus. Ed. María Rosa Menocal, Raymond P. Scheindlin and Michael Sells. Cambridge: Cambridge University Press, 2000. 435-454.

9 It was this course which motivated me to work toward the English Master's program "Interdisciplinary Studies of the Middle East” which starts at Freie Universität Berlin in the Fall of 2020. 10 There exist sufficient translations to allow opening a course on modern Arab-Jewish literature to non-Arabists. See, for example, Alcalay (1996), Neuwirth and Jamoud (2007), Behar and Ben-Dor Benite (2013), and Snir (2019). 
Cohen, Mark R. "The Neo-Lachrymose Conception of Jewish-Arab History.” Tikkun 6 (1991): $55-60$.

Cohen, Mark R. “The 'Golden Age’ of Jewish-Muslim Relations: Myth and Reality.” A History of Jewish-Muslim Relations: From the Origins to the Present Day. Ed. Abdelwahab Meddeb and Benjamin Stora. Princeton and Oxford: Princeton University Press, 2013. 28-38.

Cole, Peter. The Dream of the Poem: Hebrew Poetry from Muslim and Christian Spain, 950-1492. Princeton: Princeton University Press, 2007.

Freudenthal, Gad. "Arabic into Hebrew: The Emergence of the Translation Movement in Twelfth-Century Provence and Jewish-Christian Polemic," Beyond Religious Borders: Interaction and Intellectual Exchange in the Medieval Islamic World. Ed. David M. Freidenreich and Miriam Goldstein. Philadelphia: University of Pennsylvania Press, 2012. 124-43 (notes 203-209).

Khan, Geoffrey. "Judeo-Arabic." Handbook of Jewish Languages: Revised and Updated Edition. Ed. Lily Kahn and Aaron D. Rubin. Leiden and Boston: Brill, 2017a. 22-63.

Khan, Geoffrey. "Orthography and Reading in Medieval Judaeo-Arabic." Arabic in Context: Celebrating 400 Years of Arabic at Leiden University. Ed. Ahmad Al-Jallad. Leiden: Brill, 2017b. 395- 404.

Levy, Lital. "Historicizing the Concept of Arab Jews in the Mashriq." The Jewish Quarterly Review 98.4 (2008): $452-469$.

Levy, Lital. "Partitioned Pasts: Arab Jewish Intellectuals and the Case of Esther Azharī Moyal (1873-1948)." The Making of the Arab Intellectual: Empire, Public Sphere and the Colonial Coordinates of Selfhood. Ed. Dyala Hamzah. Abingdon: Routledge, 2013. $128-163$.

Levy, Lital. "The Arab Jew Debates: Media, Culture, Politics, History." Journal of Levantine Studies 7.1 (2017): 79-103.

Neuwirth, Angelika and Nesrine Jamoud, editors. Zieh fort aus deiner Heimat, dem Land deiner Väter... Arabische Kurzprosa irakisch-jüdischer Autoren in Israel. Berlin: Schiler, 2007.

Snir, Reuven. "Arabic in the Service of Regeneration of Jews. The Participation of Jews in Arabic Press and Journalism in the 19th and 20th Centuries." Acta Orientalia Academiae Scientiarum Hungaricae 59.3 (2006): 283-323.

Snir, Reuven. Arab-Jewish Literature: The Birth and Demise of the Arabic Short Story. Boston: Brill, 2019.

Starr, Deborah A. and Sasson Somekh. Mongrels or Marvels: The Levantine Writings of Jacqueline Shohet Kahanoff. Stanford: Stanford University Press, 2011.

Steinschneider, Moritz. Die arabische Literatur der Juden. Ein Beitrag zur Literaturgeschichte der Araber, grossenteils aus handschriftlichen Quellen. Frankfurt a. M.: Verlag von J. Kauffmann, 1902.

Teller, Adam. “Revisiting Baron's 'Lachrymose Conception': The Meanings of Violence in Jewish History.” AJS Review 38.2 (2014): 431-439. 